\title{
COVID-19 and Maintaining Public Health within Student Community: Moral Difficulties Faced by Students
}

\author{
Volha Paulava ${ }^{1, *}$, Tetyana Kamenska ${ }^{2}$, Olena Terzi ${ }^{3}$, Viktoriia Borshch ${ }^{4}$ \\ ${ }^{1}$ Department of Philosophy, Odessa National Maritime Academy, Odessa, 65029, Ukraine \\ ${ }^{2}$ Department of Sociology, Odessa I. I. Mechnikov National University, Odessa, 65089, Ukraine \\ ${ }^{3}$ Department of Forensic Medicine, Odessa National Medical University, Odessa, 65026, Ukraine \\ ${ }^{4}$ Vice-rector for Prospective Development, Odessa National Medical University, Odessa, 65026, Ukraine
}

Received July 15, 2021; Revised August 14, 2021; Accepted September 23, 2021

\section{Cite This Paper in the following Citation Styles}

(a): [1] Volha Paulava, Tetyana Kamenska, Olena Terzi, Viktoriia Borshch, "COVID-19 and Maintaining Public Health within Student Community: Moral Difficulties Faced by Students, "Universal Journal of Public Health, Vol. 9, No. 5, pp. 240 - 252, 2021. DOI: 10.13189/ujph.2021.090506.

(b): Volha Paulava, Tetyana Kamenska, Olena Terzi, Viktoriia Borshch (2021). COVID-19 and Maintaining Public Health within Student Community: Moral Difficulties Faced by Students. Universal Journal of Public Health, 9(5), 240 252. DOI: 10.13189/ujph.2021.090506.

Copyright $\odot 2021$ by authors, all rights reserved. Authors agree that this article remains permanently open access under the terms of the Creative Commons Attribution License 4.0 International License

\begin{abstract}
The research was aimed to develop a set of recommendations on maintaining public health within student community. For the practical achievement of the research goal, there were studied: students' self-perceived health status and their physical and moral reaction to COVID-19; their thoughts while onlooking relatives' reaction in the conditions of self-isolation, and students' opinion on new interaction with tutors in frame of online education. This part of the research was carried out from November, 2020 till May, 2021. Respondents were the students of South region of Ukraine, who study disciplines with some risk for public health system, namely, future seafarers and medical workers. In our work we drew on theoretical and practical conclusions made by the American, European and Ukrainian researchers of public health system and of cooperation between a teacher and a student in the conditions of COVID-19 pandemic. The theoretical aspect devoted to specification of such concepts as "public health", "public health within student community", is connected with the practical one, and allows to elaborate the unique research tooling and to reflect its components during a sociological poll with the help of questionnaire analysis. Application part of work is based on an empirical social research of transformations of students' feelings and opinions under the influence of
\end{abstract}

pandemic, drawing on the analysis of moral difficulties that the students of higher educational institution faced in terms of sudden and drastic change to a remote format of learning being fully separated from an educational group. Recommendations and conclusions are made by the authors in order to safeguard public health within student community.

Keywords COVID-19, Public Health, Public Health within Student Community, Moral Difficulties, Academic Interplay, Online Mode of Education, Academic Alienation, University Digital Ethics Code, Centre for Public Health and Psychological Academic Follow-Up of Students

\section{Introduction}

This research is a planned, system, evaluative, collective work in the frame of cross-disciplinary project "Multidisciplinary Research of Maintaining Public Health within Student Community". The group of authors who worked on implementation of the research hypothesis is part of joint academical community in Odessa. They 
examine social, moral, legal, and economic problems of public health in Ukraine. It is essentially important to emphasize that the group consists of scientists from various disciplines, namely the philosopher, the sociologist, the legal theorist, and the economist who systematically research the phenomenon of public health within student community [1-7].

The general idea of carrying out a large-scale multi-stage research in the field of public health within student community started up at the end of 2019 due to cardinal changes in the field of public health caused by COVID-19 pandemic as well as by new understanding of educational services quality in Ukraine. The initial stage of the research resulted in publication in 2020 [7]. In the present article we deliver the research practice results received during the second stage. In particular, conclusions of the original startup research project are being specified and elaborated in a new aspect. Emphasis is made on maintaining public health within student community which, in our general opinion, is of paramount importance in the conditions of a global pandemic.

Specifically, the second stage of the research was carried out from November, 2020 till May, 2021 at Odessa National Maritime Academy, Odessa Mechnikov National University under the charge of Doctor of Sociological Sciences T. Kamenskaya, the famous Ukrainian expert in the field of sociology of education [5, 6], as well as at Odessa National Medical University by V. Borshch and O. Terzi, the practical specialists in the field of public health [1-4].

The researchers propounded the following hypothesis: since in the face of protective measures from COVID-19 the students, as an active and mobile youthful group, feel uncomfortable with online education mode, it can cause destabilization of moral attitudes, and, as a result, can negatively affect public health within student community.

The decline of public health within student community is partly due to the fact that the eastern European legislative system does not refer to a student as a subject of educational services [8]. Therefore, state and university authorities take decisions neglecting possibility of moral difficulties within student community.

Presumably, some measures may improve situation with moral imbalance and difficulties within student community. In particular: on the part of education institution authorities - organization of the Centre for Public Health and Psychological Academic Follow-Up for Students, on the part of university community - the introduction of the local (inner university) Code of Digital Ethics, elaboration of educational courses that are oriented on health-saving educational technologies and on health-saving consciousness within education environment, on the part of students - active adaptation and implementation of health-saving educational technologies.

In this research the authors got specified empirical data on uncovering conditions for maintaining public health within student community based on the materials from educational institutions of Odessa city (Ukraine). They formulated a number of essential multiple-level recommendations to improve a system of public health of a higher educational institution on the Ukrainian soil during the pandemic.

\section{Methods}

\subsection{General Information}

The study was carried out as a system, collective study of conditions for maintaining public health on the territory of Ukraine in the frame of long-term project "Multidisciplinary Research of Maintaining Public Health within Student Community". The group of authors who worked on this research implementation belongs to a permanent joint academical community of Odessa city. As research platforms acted Odessa National Maritime Academy, Odessa Mechnikov National University, and Odessa National Medical University.

The empirical part of research is focused on monitoring dynamics of public health stability within student community during COVID-19 pandemic in aspect of moral difficulties faced by the students who suddenly found themselves practicing a digital mode of education [7-29].

The theoretical aspect of work is dedicated to specification of the concepts "public health", "public health within student community" and based on the following works [1-6, 30-46].

The object of the study are factors of public health stability in student community during COVID-19 pandemic in terms of sudden and drastic transit to a remote format of learning being fully separated from educational group.

The subject of the study is the phenomenon of moral difficulties faced by the students of a higher educational institution during COVID-19 pandemic.

The hypothesis of the study: since in the face of protective measures from COVID-19 the students, as an active and mobile youthful group, feel uncomfortable with online education mode, it can cause destabilization of moral attitudes, and, as a result, can negatively affect public health within student community.

The purpose is elaboration of recommendations on maintaining public health within student community.

The following research methods were used in the study:

- empirical methods (scientific papers examination; content analysis of relevant sources; monitoring of research publications; quantitative sociological methods);

- methods of theoretical analysis (induction and deduction; comparative and retrospective analysis; 
classification; specification and generalization; conceptional and categorical analysis of terms).

\subsection{Three Stages of the Research}

The architecture of the research of public health phenomenon within student community during the period of COVID-19 pandemic in aspect of students' moral difficulties included three stages.

The $1^{\text {st }}$ stage: literature review in the field of public health within student community, analytics and accumulation of statistical data. Upon completing literature review we could formulate a research objective which was verified at the next stage.

The $2^{\text {nd }}$ stage: the field stage of raw information collection (respondents' interview with google-form questionnaires in terms of isolation because of COVID pandemic).

In the first project definition phase there were formed: program of empirical researches; working groups on particular higher educational institutions in the southern region of Ukraine; the survey samples including 277 persons were worked out; the research tools were defined (interview, questionnaires).

The research was carried out on certain example of students' self-perception. They study disciplines with some risk for public health system (future seafarers and medical workers) at Odessa higher educational institutions (southern region of Ukraine).

During the second phase of empirical researches the data collection was carried out by the method of personal interview combined with questioning in the frame of established sample. Intermediate adjustment and control of previously received results (primary control).

During the third phase of an empirical research the analysis of one-dimensional distribution of respondents' answers (statistical analysis), check of a hypothesis and interpretation of the obtained quantitative data were carried out. Final processing of the received results and their interpretation were made; electronic bases of empirical data on sample were created; the final results analysis was carried out. Control of the sample statistical parameters was held while comparing the key parameter of actually received sample to the set one using Excel 2010 MS program (as a standard application to MS Office). As a result, the descriptive statistics with linear distribution of answers was received.

Thus, as concrete results of an empirical phase there can be considered the fact of students' low-grade academic alienation, and therefore, the field of public health within student community may be destabilized.

The $3^{\text {rd }}$ stage: the research results were summed up, experiment indicators were analyzed, the planned research objective was achieved, a number of essential multiple-level recommendations for maintaining public health within student community were formulated.
And, at last, after discussion, authors made a conclusion.

\section{Literature Review}

We were monitoring the publication activity on the research issue throughout the research period. The final literature on this issue contains 45 publications, including some articles in journals indexed in databases WoS and SCOPUS.

In order to raise a degree of reliability of the present research, it was decided to monitor printing activity in two directions that form an integrated and comprehensive view of a problem.

First, to examine research activity on public health phenomenon in aspect of maintaining its stable dynamism, in particular, mutual influence of public health and educational environment.

Second, to review publications on a problem of students' moral difficulties in connection with unplanned change of the education mode. Particularly, change of offline (classroom) training in the conditions of natural educational communications onto full online (out-of-class) training in the conditions of quarantine restriction at home (in this case psychologists use the term "digital isolation").

Following on from the results of the most significant references review which is provided in this article [1,33, $34,41,46]$, we can state a fact of research activity increase regarding phenomenon of public health both in international scientific community in general, and in its Ukrainian segment. Because this problem has the direct practical importance for the solution of global problems which came into existence due to COVID pandemic.

For example, the article «Attitude towards Coronavirus Pandemic «Covid-19» and Its Relationship to Optimism and Pessimism among a Sample of Residents in Irbid» (M. Hasan, M. Ma'abreh, A. Al-Masri) reveals connection between Corona disease and optimism and pessimism among the sampled population in the city of Irbid (Jordan). As the variables there were taken education and age. The article shows different level of optimism demonstrated by the youthful and the people of their late 40s and older. The youngsters turned out to be more optimistic. At the same time there is no statistically important difference considering the variable "educational background" [22].

Following on from the results of the most significant references review [1, 5, 10, 24, 35, 36, 38, 40, 43, 44], we can state insufficiency and complexity while dealing with practical evaluations of a phenomenon of students' moral attitudes transformations in connection with unplanned change of the education mode in higher educational institutions, and unprepared transition from the classroom (offline) mode to the mode of full online training at home, both lectures and seminars. Unsupervised activities were 
carried out in the remote mode, without direct contact with the lecturer and fellow students. Since the search of possible ways of solving the problem has the high practical importance for the new competitive strategy elaboration by Ukrainian higher educational institutions in education market in terms of pandemic restrictions, therefore, in-depth study of this problem is justified, and regarding its results when carrying out educational process design, can launch not only obvious improvement of educational services quality, but also, which is more important at the moment, - can increase stability of public health over the long run.

\section{Results}

On the basis of literature review carried out in this research we got the bench-mark data which demand in-depth empirical study.

\subsection{Studying a Problem of Public Health and Educational Environment Mutual Influence at Present}

The authors of this article are convinced that the pandemic situation as it has developed in the world can be used as an opportunity, "as a springboard" for "reset" (K. Schwab) and renewal [37]. But with a necessity to consider a dominant of stability in public health!

When we were only planning the purposes of our research, we were under the impression of conclusions made by Darío Salas Sommer in his book "Morals of the $21^{\text {st }}$ Century" [33]. The contemporary philosopher with conviction and excitement speaks about the necessity to form a new moral system in which basic constants of mankind existence will be considered, in particular, unity of moral aspirations, understanding of their special importance for preservation of mankind in the future world filled with new global threats. From our point of view, maintaining the balance of public health system undoubtedly is in row of such basic existential constants. We back up D. Sommer's conclusion that the moral behavior of the person is mostly favorable to the person $\mathrm{him} / \mathrm{herself}$, though it is difficult to accept direct combination of two concepts "morals" and "benefit" for a not prepared person [33]. And, therefore, acceptance of moral constants as conventional rules of maintaining "naturally focused" behavior, i.e., corresponding to "benefits" of the nature, expands us up to understanding of collective responsibility for maintaining stability of public health.

The following message by which we were guided starting research, is an obvious conclusion that exactly the higher education system is the field where many behavioral strategies in society are formed, for example, communicative, ethical, esthetic and many others. Sharon
Todd makes similar conclusion in his article «Culturally reimagining education: Publicity, aesthetics and socially engaged art practice», placing emphasis on the necessity to return performatory, esthetic practices to education [42]. We actualize the problem of moral regulators of pedagogical cooperation within the system "teacher-student" in terms of digitalization. Additionally, it is worth referring to classical work of the French sociologist Bruno Latur who characterizes modern society as a multiactor system with multilateral solution of ethical problems [31].

Thus, our intermediate conclusion is obvious: education and public health are connected through social regularity. But by virtue of the fact that global COVID pandemic dealt a serious blow to social stability it is necessary to observe and monitor the moral aspect changes during the pedagogical cooperation within the digital environment.

\subsection{Studying a Problem of Students' Moral Attitudes Transformations in Connection with Unplanned Change of the Education Mode onto the Digital one and Looking for Possible "Health-saving" Educational Technologies}

This aspect was also examined by means of theoretical literature review. And it was placed second not because of its importance in any way, but only due to smaller number of publications and sufficient complexity of practical evaluations of the researched phenomenon of students' moral attitudes transformations in connection with unplanned change of the education mode and unprepared transition from the classroom (offline) mode to the mode of full online training at home ("digital isolation").

Famous Australian scientist, computer sciences expert, John O'Brien refers to a problem of digital ethics at the higher school in his comprehensive work published in 2020 [35]. He grounds the main conclusion: the higher education has to become leader in creation of a new digital ethics type because it is not possible to blench the approaching ethical problems. Group of authors, such as Olcott Jr. D., Carrera Farran, X., Gallardo Echenique, E. E., González Martínez, J. came to similar conclusions, analyzing transformations in education and ethics during a digitalization era. The quote from the article highlights this thought: "The authors offer a conceptual framework centered on the Ethical Context Continuum (ECC) that integrates how society, culture, values, and technology are perceived by people and create ethical choices that consider the potential harm, benefits, or both, to individuals and groups. A summary of emerging ethical issue areas is discussed and recommendations are offered for adapting global best practices and lessons learned at the local level in Catalonia. The authors conclude that the range and complexity of potential ethical issues relevant to the use of digital technologies will expand in the future. The development of a comprehensive Code of Ethics for 
the Use of Digital Technologies is strongly recommended across all societal sectors in Catalonia [36].

It is obvious that the COVID-19 pandemic only aggravated the existing problem and caused unprecedented shifts in the higher education all over the world. Amy Scott Metcalfe, practicing a photographic evidence method for the phenomenon of pandemic education, writes in her brilliant article: "Attempting to make sense of the 2020 pandemic can be understood, meta-cognitively speaking, as academia's quintessential response to the unknown, coupled with a sector-wide existential crisis" [26].

Note that one of the leading world analytical Internet platforms on services in the field of global higher education sector Quacquarelli Symonds (QS) has been monitoring the situation practically immediately after the moment it appeared [28]. There has been already accumulated a huge scope of information, and this information content is very interesting.

S. W. O'Connor, public health specialist, believes that a significant threat in terms of COVID-19 pandemic is the long social isolation. Because previously people adapted to a short-term loneliness [41].

We place the emphasis on the fact that the main moral characteristics of a modern human - call of duty, responsibility, conscience - are formed in the course of live communications during socialization, and most dynamically it happens in the course of education. Many innovators of distance education system emphasize the necessity of a special ethic expertise of this system. For example, some authors studied in 2020 the awareness of ethical problems when using system of electronic learning, particularly $\mathrm{T}$. Al Mseiedein and O. Mahasneh, but research activity of this problem field does not have mass character [44].

Another example, Olivier Marty sets the binary nature of ethical regulation: "On the one hand, one's ethics are judged according to external fitness to standards of behavior within his or her society, on the other hand, one's ethics are judged according to internal obligations to his or her profession". And claims that in the conditions of digitalization of the higher education there is a need to elaborate some special type of distance education ethics [38].

The whole range of publications deal with related topics.

In our opinion, the positive solution of this problem can be found while searching and implementing some kind of "health-saving" educational technologies. For instance, I.V. Serheta and other authors of the article examine the problem of health-saving educational technologies in frame of learning process $[19,20]$. They make theoretical conclusion that nowadays in terms of pandemic and public health destabilization, "it is very important to provide scientific evidence of psychohygienic backgrounds of health-saving technologies, to implement at higher educational institutions the health-promoting and recreational programs with their efficiency evaluation" $[19$, P. 66]. And their practical experiments prove that such measures "significantly improve education and its health-creative effect" [19, P.72-73].

Since the problem of moral difficulties origin within student community in terms of total distance learning ("digital isolation") is far from its solution, we decided to complete the theoretical part of our research with philosophical conceptional and categorical analysis of the concepts "public health", "public health within student community".

\subsection{Clarification of the Definitions of "Public Health", "Public Health within Student Community"}

From the philosophical point of view, the definition of the term «public health» can be considered from the position of different approaches. Specifically, let us apply the most common philosophical approaches, such as ethical-utilitarian, activity-based, phenomenological, and a very widespread one at present - event-ontological approach. This will allow us to trace more precisely the semantics flexibility of this term. And, as a consequence, to specify another concept - «public health within student community».

In the philosophical and ethical context, the concept of «public health» is based on utilitarian connotations. Because the achievement of collective benefit in the population health in general sets the key meaning of the term. Recall that one of the first attempts to define «public health» was made by David Atchison particularly in this way. He believed that it was not just the science of preserving and maintaining public health, but also a form of «the art of people cooperating at various levels to preserve health». Unfortunately, this approach is limited in its practical possibilities. As modern western societies are oriented mainly toward the ideas of individualism, notions of collectivist content work poorly.

Considering the problem of «public health» definition, we agree with a number of contemporary researchers [39, 41]. We believe that from the philosophical position of the activity approach the concept of «public health» can be considered as an integral system of measures, in which, according to the principle of synergy and network interaction, three types of activities are implemented: disease treatment, protective and preventive measures to preserve public health, as well as strengthening and health promotion for the population. The dominant ethical content of this concept is the ethics of paternalism, the ethics of care (in various manifestations in relation to health at the collective level).

From a phenomenological point of view, «public health» can be interpreted as a meta-complex, multicomponent phenomenon of maintaining social existence in a harmonious, natural, dynamically balanced 
state, in which each member of a given society can successfully perform his or her functions while maintaining a sufficient life expectancy. The dominant ethical content of the term is the ethics of communitarianism. That means that the phenomenon of public health can only be achieved through the relatively equal joint actions of all society members; what matters is the balance of the efforts of the steering expert group (health care system authorities) and the awareness of the actions of all members of a given society. From such ethical-philosophical positions, the individual and the collective must be in unity and balance, but in reality, with the dominance of a paternalistic health care system, this is hard to achieve.

The Event Ontology is a very popular trend in modern philosophy. In our opinion, the tools of the Event Ontology can be applied to define the term "public health" as well. And particularly in this interpretation the inner content of this concept is most clear-eyed understood. From the perspective of Event Ontology, public health can be described as an emerging, incomplete "event" created by all the participants of a given society, aimed at social effectiveness in the fight against disease. Exactly from this research position, using the method of event ontology, we believe it will be useful to specify the concept of "public health" through the definition of "public health within student community". If we consider public health within student community as a relatively independent subsystem of public health, it allows us to emphasize the interrelation of social systems of health and education. The ontological event-based interpretation of «public health within student community» emphasizes the importance of individual efforts to protect health, rather than the dominance of state authorities' measures to protect collective health. Combining the concepts of «public health» and «student community» in one investigated «event space» can also be useful in terms of understanding the reorientation of managerial actions to maintain public health from the dominant model to the model of individual network efforts to maintain health. The pandemic situation of COVID-19 spread on a global scale proves that the phenomenon of health is being implemented by the collective efforts of each society member, even minimal in its efficiency! What is fundamentally important is the collectivity, the coherence of health-saving actions. Therefore, we propose to clarify the term «public health within student community» and consider it as a set of different ways to achieve collective health, which students fall back upon in order to manage the common case of health-saving in the process of study. Public institutions and private medical structures interact with the public health system (and its subsystem of public health within student community, in particular). In its turn, the public health system delegates management, expert, controlling functions, etc. to medical health structures. In this case, the authorities of the higher education institution should be focused on efficient implementation of health-saving educational technologies. Since this is already an obvious requirement of the time, and Ukraine lags far behind European standards in this matter [11-13, $16,19,24,29]$.

\subsection{Empirical Result Evaluation of the Carried-Out Research}

Since we initially aimed to analyze a phenomenon of moral difficulties faced by higher educational institution students in terms of sudden transit to a remote format of training being fully separated from educational group, the questions offered to the respondents were divided into two blocks.

For drawing up tools of collecting primary sociological information we formulated the questions $(1,2$ and the last $9,10,11)$ revealing the general perception by the students of the impact that COVID-19 had had on their lives, and of the pandemic shocks and commotions they had faced.

How the process of students' change-over onto the new online mode had passed, we expressed in the general question (3) and in the subsequent two mirror questions (4 and 5) therethrough we tried to reveal positive and negative perception of this process. Question 6 specified students' suggestions for the tutors. Question 7 was about students' expectations from online mode of learning. Question 8 most likely will allow to reveal whether the students feel or not the anxiety which the self-isolation period had left. Thus, two blocks of questions (1-8) reflect the attempt of our research group to learn about feelings of today students in the conditions of COVID-19 pandemic and the need of a new ethic code introduction regarding changing system of relationship in the digital educational environment. In order to simplify analytics of the obtained material collected from the respondents we marked answer options with Latin letters A, B, C, D, E and showed them on diagrams. 
Question 1: What happened to your health during the COVID-19 pandemic?

\section{Index 1. What happened to your health during COVID-19 pandemic ?}

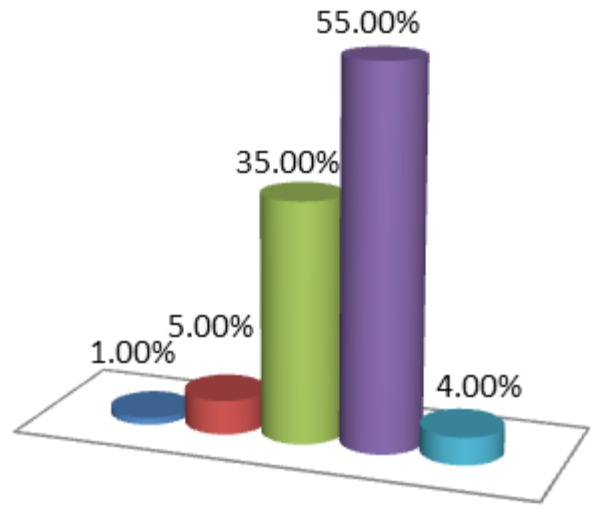

- A - I had a severe coronavirus dise ase

- B - I had moderate case

C - I had mild conditions

D - I didn't have COVID

E - other

Question 2: How did you feel about everything that happened during the pandemic with you and your friends and family?

Index 2. How did you feel about everything that happened during the pandemic to you and your friends and family?

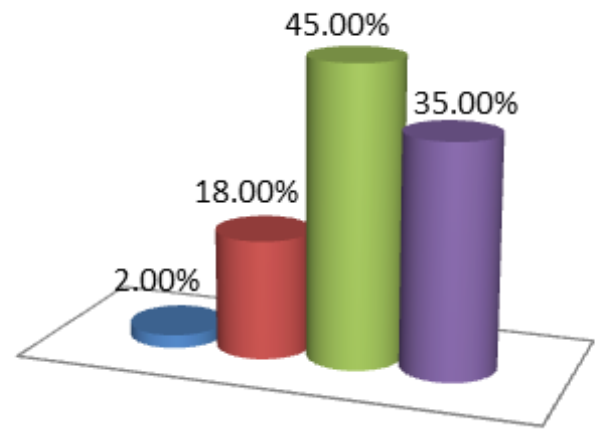

A - it was very hard, I was down and out

B - I felt anxious

- C - I was worried and felt uncomfortable but I coped with this feeling

D - I practically didn't feel any anxiety
Question 3: COVID-19 pandemic imposed new educational forms to everyone.

Index 3. COVID-19 imposed new educational forms to everyone. What is your opinion on these implementations

(in particular online education)?

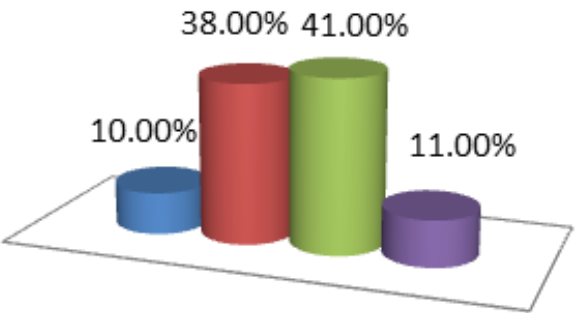

A - they must become the norm and standard practice for higher education in future

a - such forms can be implemented on a regular base along with the traditional ones

a $\mathrm{C}$ - these forms can be used occasionally and in rare circumstances

D - not sure

What is your opinion on these forms implementation (in particular online education)?

Question 4: Which is the most positive change in terms of online education that you've noticed?

Index 4. Which is the most positive change in terms of online education that you've noticed?

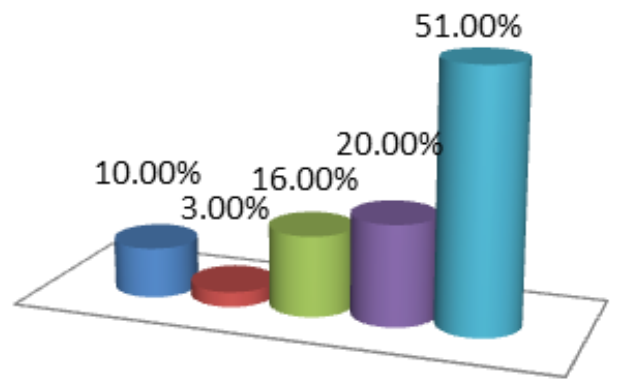

A - there is no pressure from lecturers

B - lecturers pay more attention to the course content

a C - nobody distracts my attention and bothers me during the lectures

D - it is more convenient and comfortable to answer during the seminars

E - it is easier to pass exams and tests and there's much less emotional wringer 
Question 5: Which is the most negative change in terms of online education that you've noticed?

Index 5. Which is the most negative change in terms of online education that you've noticed?

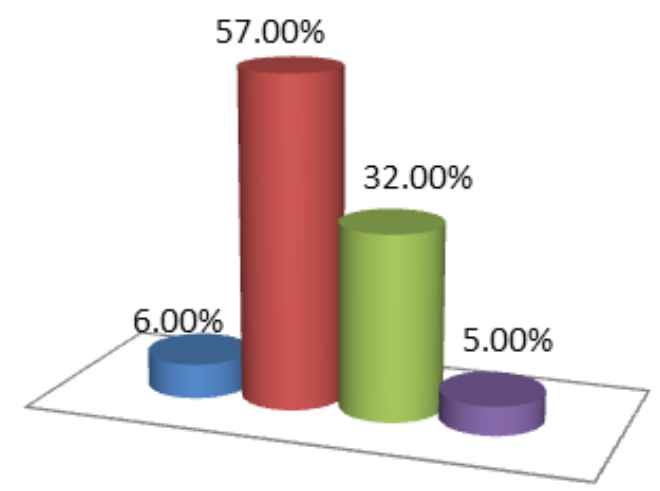

A - parents' control has become stronger

B - there is more individual and written work

- C - it has become more difficult to conceive the information

D - it has become more difficult to pass exams and tests

Question 6: How do you take the idea that universities and colleges should provide online courses during the high flu and cold season even when there is no pandemic?

Index 6. How do you take the idea that universities and colleges should provide online courses during the high flu and cold season even when there is no pandemic?

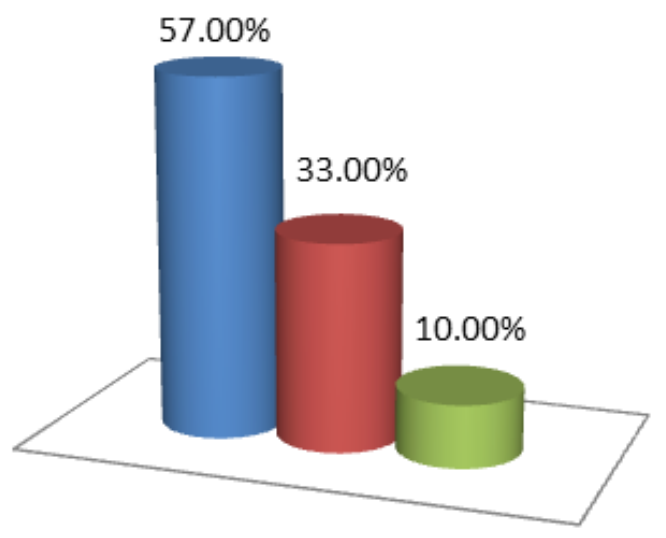

A-agree $\quad$ B - not agree $\quad$ C - cannot say
Question 7: Did you personally feel the necessity of help, moral support and countenance?

Index 7. Did you personally feel the necessity of help, moral support and countenance?

$51.00 \%$

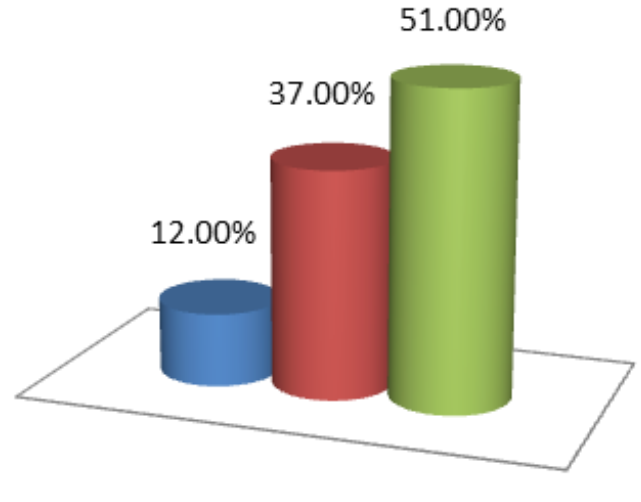

A - no, I didn't

B - yes, I did, but I coped with the situation myself

- C - yes, I did, and I was looking for such support

Question 8: Is there a need of a new ethic standard for online education?

Index 8 . Is there a need to form a new ethic standard for online education?

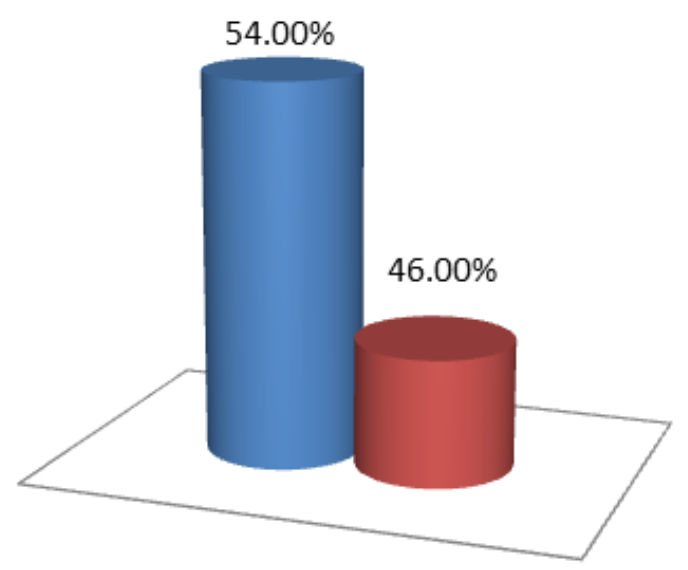

A - Yes, the new ethical standard (ethical code) of online education is necessary

B - No, the new ethical standard is not required, the common human morals is enough 
On the basis of these results we can make an intermediate conclusion that most of respondents did not experience physical health problems or difficulties during the quarantine online studying. But they had rather significant emotional stress what came out as dismal mood and search of moral support from outside. Most respondents agree that the new ethic standard of online education is necessary.

\section{Discussion}

The purpose of the research carried out by this team of authors is to attract the attention of the teaching community and of the public to the problems of relationship between public health and moral difficulties experienced by students in connection with a sharp change in the mode of study during the pandemic. Proceeding from the stated purpose of the research, we turn to the changes in moral attitudes and behavior of full-time students caused by a sharp need to remain self-isolated, to be separated from the collective and to continue studying on-line under the pressure of pandemic disease threat. In order to trace the possibilities of maintaining public health stability in such crisis situations as a pandemic, we turned specifically to the analysis of student community state. In our opinion, this community is quite sensitive to social changes, which can be seen, first of all, in moral difficulties experienced by students.

For example, the distribution of answers to question 2 (How did you react to what was happening to you and your relatives during this pandemic?) and question 7 (Did you personally feel the need for moral support and help during the pandemic?) indicates, in our opinion, that academic alienation is shown by students in a weak form. Since the affirmative answer to question 2 indicates that they did experience anxiety of various degree, mostly mild, and were able to cope with it, only $65 \%$ of respondents did answer this question. Question 7 about the need of moral support during the pandemic was answered in the affirmative by $88 \%$ of respondents in general, of which a higher percentage of students - $51 \%$ sought moral support and $37 \%$ felt the need for moral support, but tried to solve these problems on their own.

Considering the form of manifestation, we regard the phenomenon of academic alienation as a kind of social maladaptation that student community experienced. And considering the content of this phenomenon, it can be included to some sort of short-term psychogenic maladaptations, which finds its existence in various types of violations of an individual and educational environment interaction. During conversations with students in private, it was found that, under the influence of COVID-19, there was mainly a decrease in cognitive activity, a decrease in interest in competence growth, a lack of understanding of the ultimate goals and results of online learning, etc. This is also evidenced by responses to questions about changes in the learning process in connection with the "digital isolation", in particular, the respondents reported that "the amount of individual work and written assignments increased" - 57\%, "I conceive the information worse" $32 \%$ of respondents.

A relative decrease in emotional stress during online exams is indicated by the answers to question 4 ("Passing exams and tests has become easier" - as stated by $51 \%$ of respondents). This answer can be interpreted in two ways: first, were the ethical standards and norms of passing online exams similar to those of the offline ones? Second, the point concerning the nature of emotional tension requires experimental clarification.

But, as the survey showed, the online mode of learning requires its own ethical standards. By this we mean compliance with commitments to the quality of educational result and a general desire to achieve a high educational result, the conscious improvement of professional and general competencies by students in the process of learning. In confirmation, $54 \%$ of the students voted "for" the introduction of a new digital ethical standard of education.

Thus, the study recorded an increase in moral and ethical instability to a mild degree, caused by some misunderstanding and rejection of the new form of online education, with an increase in general confusion in learning process under the sharp change of education mode. This conclusion can be made based on the analysis of the answers to question 3. Since a fairly high percentage of respondents ( $41 \%$ and $11 \%$, respectively) answered that distance learning as an independent form of education can be used in exceptional cases, a high percentage of respondents found it difficult to answer. $38 \%$ of the respondents were in favor of a mixed form of learning, i.e., student communication environment is a necessary factor to maintain effective pedagogical interaction and development of the learning process.

Why do we believe that we are dealing with a mild form of students' academic alienation of psychogenic nature?

More severe forms of alienation are reflected not only in moral instability, but also in the appearance of deviant behavior in the learning process (skipping classes, ignoring tests, exams, bullying in the learning environment, etc.). [15, 20, 21, 23, 27, 28, 32, 46].

Thus, the hypothesis of the study "since students as an active and mobile youth group may feel uncomfortable in on-line format of education under COVID-19 protective measures, it can cause destabilization in the sphere of mental and moral attitudes, and as a result, can have a negative impact on public health within student community" - is proved.

Let's remind, that the authors studied the general moral and ethical state of students in connection with the abrupt change of forms of education from full-time to distance 
learning in terms of COVID-19 pandemic. Deviant behavior with sharp deviation from the requirements of the academic standard of behavior was not revealed in our experimental observation. We should note that research on bullying in academic community is quite complex and has not been carried out as a part of this study.

Summing up the academic results of the academic year and the analysis of the academic records shown by the interviewed students in various disciplines, indicates the achievement of the average academic result by students at the end of academic year, which took place in such «non-standard» conditions of «digital isolation». Although students' academic grades do not support the thesis that "passing exams and tests has become easier".

Academic alienation of students in the theory of public health is considered as a reversible and successfully preventable process $[15,32,46]$. On this basis, we believe that with the strengthening of skillful pedagogical influence, taking into account targeted work with the consequences of academic alienation it is possible to achieve effective results in eliminating this negative and dangerous phenomenon. Any education has to reckon with natural tendencies of the brought up [45]. So, our group has the intention to continue monitoring and analyzing the results obtained. We believe that in the future we could examine the problems of digital bullying in educational environment of a higher education institution.

Thus, we studied the problem of preserving public health through the study of students' reaction to the abrupt change in modes of learning, to how students underwent moral readjustment to the new mode of online learning and what moral difficulties they experienced as a result of the reformatting of the educational process. The alarming results of the study of students' moral and ethical difficulties undoubtedly lead us to the conclusion about the need to introduce "health-saving" learning technologies and update the standards of ethical regulation with the transition of educational process to digital environment in order to maintain public health.

\section{Conclusions}

We believe that this collective study on maintaining public health through the identification of students' moral difficulties during the COVID-19 pandemic has achieved its planned goal. The planned sociological experiment covering 277 respondents was carried out. The indicators which allowed to conclude about the appearance of negative phenomenon of academic alienation within student community during the abrupt change of educational format were revealed. The philosophical understanding of the basic definitions of this study (public health and public health within student community) through different philosophical approaches was clarified. The leading hypothesis of the study is proved.
Based on the above, let's summarize and formulate some multi-level recommendations:

1. At the level of the Ministry of Health of Ukraine we recommend:

- to intensify educational work in the field of public health, which is considered as a cumulative system of knowledge and organized measures taken by actors to promote health and counteract disease, with improved quality and life expectancy of the population of Ukraine.

2. At the level of higher education authorities, we recommend:

- first, to take into account in the organizational work that it is institution authorities who are fully responsible for maintaining public health in the educational environment of a higher education institution. Consequently, it is the authorities of the higher education institution who should accumulate initiatives to create a new academic code of behavior in terms of educational process digitalization (i.e., the "University Code of Digital Ethics").

- second, the detected phenomenon of academic alienation can be eliminated by preventive measures. Consequently, the university administration is recommended to take this fact into account when designing educational programs for specialties and strive to neutralize this negative phenomenon by strengthening the humanitarian component of educational programs. Because the development of students' soft skills, in particular, critical thinking, emotional intelligence, empathy ability, strengthening of intellectual health, strengthening of collective interaction skills, etc., leads to better academic adaptation in difficult pandemic conditions and, as a consequence, contributes to the stabilization of public health.

- third, to promote and disseminate the experience of implementing "health-saving" pedagogical design through the creation of a specialized university Center of public health and psychological and pedagogical support for students.

3. At the level of teachers-practitioners, especially philosophers, sociologists, lawyers, medics as conscious bearers of the initiative of public health stabilization in the educational environment, we recommend:

- firstly, to strengthen the research interest and effectiveness in comprehending a new kind of etiquette communication in digital format and to elaborate collectively a "Code of Digital Ethics" of the university community, taking into 
account different characteristics of each higher education institution.

- secondly, when carrying out procedures of pedagogical design (planning the structure, content, methods of presenting educational material and methods of educational results diagnostics) of courses to focus on "health-saving" methods and technologies, because the meta-task of a teacher, in our opinion, is not only to give knowledge to a future specialist, to develop a set of necessary competencies, but, having preserved personal health, to stabilize public health in perspective.

- thirdly, to study advanced European and domestic experience on organization and activity of public health centers and psychological and pedagogical support for students, to develop a possible model of such center in the university.

4. At the level of collective carriers of public health in educational environment (teachers, students, parents, etc.) we recommend:

- to approach these problems consciously and understand that health is not a givenness. As a complex and fragile system, it is created at different levels (individual, group and community). At each of these levels, integrity and coherence are important. Especially during the COVID-19 pandemic it is necessary to comprehensively consider all factors of public health in the educational environment, with a mandatory emphasis on a moral component of each participant behaviour in the field of education.

5. The authors of this study respect the achievements of academic freedom in the educational space of universities. But given the pandemic realities, it is necessary to come to a revision of collective moral attitudes and previous agreements. In our opinion, the "code of digital ethics" of the university community implies an increased attention to the norms of behavior in the "digital" environment, highlighting the independent principles of communication "digital etiquette" in educational process.

Therefore, our goal for the follow-up study is to examine connection between digital bullying and ethical standards of public health within academic environment of a higher education institution.

\section{Acknowledgements}

The study was carried out with the assistance of the East European Scientific Group and the cross-disciplinary project "Multidisciplinary Research of Maintaining Public Health within Student Community". The authors thank reviewers for their useful comments on the article.

\section{REFERENCES}

[1] O. O. Terzi, N. O. Liakhova, \& T. V. Pluzhnikova, Pravovi ta etychni zasady hromads'koho zdorov"ya // Visnyk sotsial'noyi hihiyeny ta orhanizatsiyi okhorony zdorov'ya Ukrayiny, (3), 84-90, 2019 [in Ukrainian].

[2] O. Terzi Praktyka pryynyattya etychnykh kodeksiv u sferi okhorony zdorov'ya v Ukrayini ta v inshykh krayinakh // Pryvatne ta publichne pravo.,1/18, T.4, Pp. 58-61, 2019 [in Ukrainian].

[3] O. Terzi, Naukovi pidkhody shchodo systematyzatsiyi medychnoho zakonodavstva // Pivdennoukrayins'kyy pravnychyy chasopys ODUVS, № 3, Pp. 95-98, 2018. URL: https://repo.odmu.edu.ua:443/xmlui/handle/123456789/70 18 [in Ukrainian]

[4] O.O. Terzi, N.A. Lyakhova, V. G. Marichereda, S. B. Melnyk, V.I. Borshch, Organizational, regulatory and legal aspects of European integration of higher medical education in Ukraine: A critical review // Widomocsi Lekarskie, 73 (6), Pp. 1290-1296, 2020 URI: https://repo.odmu.edu.ua/x mlui/bitstream/handle/123456789/8109/Marichereda.pdf?s equence $=1$

[5] T.G. Kamenskaya, Sotsial'noye znaniye i virtualizatsiya sotsial'noy real'nosti / T.G. Kamenskaya. Odesa: Astroprint, 280 p., 2009 [in Russian]

[6] T.G. Kamenskaya, Sotsiologiya obrazovaniya / T.G. Kamenskaya. - Odesa: Pechatnyy dom, 172 p., 2013. [in Russian]

[7] V. Paulava, A. Nerubasska, I. Kuzmenko, T. Yamilova, L. Zahorodnia, Research of Satisfaction of Quality of Educational Results from the Viewpoint of Education / Services, Universal Journal of Educational Research, Vol.8, Pp. 3655-3665, 2020.

[8] V. Okulich-Kazarin, Are Students of East European Universities Subjects of Educational Services? Universal Journal of Educational Research, 8(7): pp. 3148-3154, 2020. DOI: $10.13189 /$ ujer.2020.080743

[9] A. A. Artemenkov, Otsenka psikhoemotsional'nogo sostoyaniya studentov universiteta. Gigiyena i sanitariya. № 4, S. 73-76, 2013. [in Russian]

[10] A. Jones, R. Bennett, Reaching beyond an online/offline divide: invoking the rhizome in higher education course design // Studies in higher education, Vol.26, N.2, Pp.193-210, 2017.

[11] A. De Giusti, «Policy Brief: Education during COVID-19 and beyond», TEyET, № 26, p.12, oct. 2020.

[12] A. Witze, Universities Will Never be the Same After the Coronavirus Crisis. // Nature, June 1, 2020. https://www.n ature.com/articles/d41586-020-01518-y 
[13] C. R. Boot, P. Vonk, F. J. Meijman, Health-related profiles of study delay in university students in The Netherlands. Int J. Adolesc Med Health.76, Vol. 19, № 4. P. 413-423, 2007.

[14] D. Aherne, Mindfulness based stress reduction for medical students: optimising student satisfaction and engagement. BMC Medical Education. T. 16. № 1. P. 209, 2016.

[15] D. B. Center, Social Maladjustment: Definition, Identification, and Programing // Focus on Exceptional Children, 09/01, Vol. 22, Pp. 1-11, 1989.

[16] F. Quattrone, A. Borghini, M. Emdin, Protecting higher education institutions from COVID-19: insights from an Italian experience, Journal of American college health, 2020. Ahead-of-print, 1-2 https://doi.org/10.1080/0744848 1.2020.1791885

[17] F. van Schalkwyк, Reflections on the public university sector and the COVID-19 pandemic in South Africa, Studies in higher education, Vol.46, N. 1, P.44-58, 2021.

[18] I. G. Kretova, O. V. Belyayeva, O. I. Shiryayeva, Vliyaniye sotsial'nykh i psikhologicheskikh faktorov na formirovaniye zdorov'ya studentov $\mathrm{v}$ period obucheniya $\mathrm{v}$ vysshem uchebnom zavedenii. Gigiyena i sanitariya. № 4. S. 85-90, 2014 [in Russian]

[19] I. V. Serheta, I. L. Drezhenkova, N. V. Stoyan, Zdorov'yazberihayuchi tekhnolohii ta osoblyvosti yikh zastosuvannya $\mathrm{v}$ suchasnykh zakladakh vyshchoyi osvity $\mathrm{u}$ konteksti formuvannya efektyvnoyi systemy hromads'koho zdorov'ya: psykhohihiyenichni osnovy - Poltava: TOV Firma «Tekhservis», S. 65-76, 2009 [in Ukrainian]

[20] I. V. Serheta, L. I. Hryhorchuk, O. P. Molchanova, Shlyakhy optymizatsiyi profesiynoyi adaptatsiyi studentiv do umov navchannya $u$ medychnomu vyshchomu navchal'nomu zakladi ta yikh prohnostychna znachushchist'. Dovkillya ta zdorov'ya. № 4 (23). S. 57-61, 2002. [in Ukrainian]

[21] L. Andrew, Rising Student Mental Health Problems Need Urgent Attention. University World News, September 19, 2020.https://www.universityworldnews.com/post.php?stor $\mathrm{y}=20200918101649827$

[22] M. Hasan, M. Ma'abreh, A. R. I. Al-Masri, Attitude towards Coronavirus Pandemic «Covid-19» and Its Relationship to Optimism and Pessimism among a Sample of Residents in Irbid, Universal Journal of Public Health, Vol. 9, No. 1, pp. 1 - 17, 2021. DOI: 10.13189/ujph.2021.090101.

[23] O. Daniel, M. Farley, E. Christiansen, H. Pettersson, E. Clark Social maladjustment and students with behavioral and emotional disorders: Revisiting basic assumptions and assessment issues // Psychology in the Schools (41) 2004/11/01, P.835-847/ URL: https://www.researchgate.ne t/publication/227762733_Social_maladjustment_and_stud ents_with_behavioral_and_emotional_disorders_Revisitin g_basic_assumptions_and_assessment_issues

[24] Obrazovaniye 20.35. Chelovek / ASI. - Yekaterinburg: Izdatel'skiye resheniya, T. 7. 152 s., 2017 [in Russian]

[25] QS. 2020. The Impact of the Coronavirus on Global Higher Education. https://www.qs.com/portfolio-items/the-impact -of-the-coronavirus-on-global-higher-education/. [Google Scholar]
[26] S.A. Metcalfe, Visualizing the COVID-19 pandemic response in Canadian higher education: an extended photo essay, Studies in Higher Education, Vol. 46, N. 1, P. 5-18, 2021.

[27] V. A. Ohnyev, N. O.Halicheva, K. M.Sokol, S. H.Usenko, N. M.Fedak, M. D. Rubins'kyy, Z. P.Petrova, L. I.Chumak, O. V. M'yakyna, Sotsial'nopsykholohichni osoblyvosti sposobu zhyttya studentiv ta yikh vplyv na zdorov'ya. Eksperymental'na i klinichna medytsyna. № 1. S. 164-169, 2012 [in Ukrainian]

[28] V. V. Bespal'ko, Medyko-sotsial'ni problemy dezadaptatsiyi student. s'koyi molodi. Odes'kyy medychnyy zhurnal. № 5. S. 77-81, 2004. [in Russian]

[29] W. El Ansari, C. Stock, Is the health and wellbeing of university students associated with their academic performance? Cross sectional findings from the United Kingdom, Int J Environ Res Public Health. Feb;7(2). P.509-27, 2010.

[30] Aktual'ni pytannya pravovoho zabezpechennya diyal'nosti systemy okhorony zdorov'ya Ukrayiny $\mathrm{v}$ umovakh pandemiyi koronavirusnoyi infektsiyi (COVID-19) / O. O. Terzi, I. Z. Hladchuk, N. O. Lyakhova, T. V. Pluzhnikova // Hromads'ke zdorov'ya v Ukrayini: realiyi, tendentsiyi ta perspektyvy: kolektyvna monohrafiya / za zah. red. prof. Zhdana V. M. ta prof. Holovanovoyi I. A. - Poltava: TOV «Firma «Tekhservis», - P. 184-191, 2020.URL: http://elibumsa.pl.ua/handle/umsa/12863 [in Ukrainian]

[31] B. Latour, Reassembling the Social: An Introduction to Actor-Network-Theory (Clarendon Lectures in Management Studies), 320 p., 2007.

[32] E. R. Borinshteyn, Vzaimnaya sotsial'naya adaptatsiya kak faktor koevolyutsii obshchestva // Sotsial'nyye tekhnologii. №.20, P. 20-25, 2003. [in Russian]

[33] D.S. Sommer, J. Baines, Ecología interior: moral para el siglo XXI. Xistral, 617, 2007.

[34] H.V. Huseva, \& S.H. Ubohov, Zakonodavchi aspekty zabezpechennia dotrymannia etychnykh norm u sferi okhorony zdorovia [Legislative aspects of ensuring ethical compliance in the healthcare sector]. Intehratyvna Antropolohiia - Integrative Anthropology, 1 (27), 17-21, 2016 [in Ukrainian]

[35] J. O'Brien, Digital ethics in Higher education // Educaus Rerevew, issue \#2, p.p 12-43, 2020 https://er.educause.edu/-/media/files/articles/2020/5/er20_2 103.pdf

[36] Jr. D. Olcott, C. Farran, E. Gallardo, \& G. Martínez, Ethics and Education in the Digital Age: Global Perspectives and Strategies for Local Transformation in Catalonia. RUSC. Universities and Knowledge Society Journal, 12(2). P. 59-72, 2015.

[37] K. Schwab, Th. Malleret, COVID-19: The Great Reset, Paperback, July 9, 280 p., 2020.

[38] O. Marty, Distance education ethics: How technique impacts morality and deontology. 2014. ffhalshs-01233793f

[39] Proekt zakonu Ukrayiny «Pro systemu hromads'koho zdorov'ya» (Draft Law of Ukraine «On the Public Health 
System»), Nomer, data reyestratsiyi: 4142 vid 22.09.2020 URL: http://w1.c1.rada.gov.ua/pls/zweb2/webproc4_1?pf3 511=70025. [in Ukrainian]

[40] R. Apresyan, Eticheskoye regulirovaniye zhizni universiteta: vozmozhnosti i opyt // Utopiya i obrazovaniye: Sbornik trudov Mezhdunarodnoy nauchno-prakticheskoy konferentsii / Gl. red.: I.V. Melik-Gaykazyan. - Tomsk, P. 28-51, 2011. [in Russian]

[41] S. W. O'Connor, 4 Key Public Health Issues in 2021, April 20, 2020.https://www.northeastern.edu/graduate/blog/publ ic-health-issues/

[42] Sh. Todd, Can there be pluralism without conflict? Ingesting the indigestible in democratic education // Journal of Philosophy of Education Annual Conference, Vol. 3, P. $1-11,2009$.

[43] Sh. Todd, Culturally reimagining education: Publicity, aesthetics and socially engaged art practice. Journal of
Educational Philosophy and Theory, Volume 50, P. 970-980, 2018.

[44] T. Al Mseiedein \& O. Mahasneh, Awareness of Ethical Issues when using an e-Learning System, International Journal of Advanced Computer Science and Applications. Vl. 11, 2020.

[45] S. Belentsov, A. Fahrutdinova, V. Okulich-Kazarin, Education of Civic Consciousness in George Kershenshteyner's Creativity. European Journal of Contemporary Education, 6(1), P. 5-13, 2017.

[46] M. Orlenko, Philosophical underpinnings of the concept of social maladjustment in the modern world / I. M. Orlenko // Philosophical and methodological challenges of the study of modern society: collective monograph / T. V. Andrushchenko, Z. M. Atamaniuk, E. R. Borinshtein, Y. A Dobrolyubska, etc. - Lviv-Toruń: Liha-Pres, P. 149-167, 2019. 